Salindri Wandestari ${ }^{1}$ Enda Puspitasari ${ }^{2}$ Yeni Solfiah ${ }^{3}$

\title{
PENGEMBANGAN MEDIA KOLAM UKUR UNTUK MENINGKATKAN KEMAMPUAN PENGUKURAN PADA ANAK USIA 5-6 TAHUN
}

\begin{abstract}
Abstrak
Penelitian ini bertujuan untuk menghasilkan produk media yang layak digunakan untuk mengembangkan kemampuan pengukuran anak usia 5-6 tahun. Jenis peneltian adalah peneltian \& pengembangan (Research \& Development) dengan mengacu pada model yang dikembangkan oleh Sugiyono. Prosedur pengembangan dilakukan melalui beberapa tahap yaitu potensi dan masalah, mengumpulkan informasi, desain produk, validasi produk dan revisi produk. Pada penelitian ini tidak ada uji coba, hanya sampai pada validasi kemudian di revisi. Hal ini dikarenakan adanya pandemi yaitu Covid-19 sehingga peneliti tidak bisa terjun langsung ke lapangan. Hasil penilaian dari ahli media mendapatkan rata-rata persentase dengan skor $80 \%$ dengan kategori layak. Hasil penilaian dari ahli materi mendapatkan rata-rata persentase dengan skor $74 \%$ dengan kategori layak. Dan hasil penilaian oleh pendidik mendapatkan rata-rata persentase dengan skor $81.71 \%$ dengan kategori sangat layak. Sehingga secara keseluruhan produk media kolam ukur hasil pengembangan dikatakan layak digunakan untuk mengembangkan kemampuan pengukuran anak usia 5-6 tahun.
\end{abstract}

Kata Kunci: Media Kolam Ukur, Pengukuran AUD

\begin{abstract}
This study aims to produce media product that feasible to be used to develop the measurement ability in children aged 5-6 years. The type of this research is research \& development (R \& D) using the development model of Sugiyono. The development procedure is carried out through several stages: potential and problem, gathering the information, product design, product validation and product revision. In this study was not conducted treatment, but only validation and revision. This is due to a pandemic Covid-19, so the researcher cannot go directly to the field. The results of the assessment of the media expert obtained the average value of $80 \%$ (feasible category). The results of the assessment of the material expert obtained the average value of $74 \%$ (feasible category). And the results of the assessment by educators obtained the average value of $81.71 \%$ (very feasible category). Based on the results of all assessment can be concluded the product of the measuring pool media development were suitable to be used to develop the measurement ability of children aged 5-6 years.
\end{abstract}

Keywords: Measuring Pool Media, Early Childhood Measurement

\footnotetext{
1,2,3) Program Studi Pendidikan Guru Pendidikan Anak Usia Dini, Fakultas Keguruan dan Ilmu Pendidikan, Universitas Riau

${ }^{1)}$ Alamat email salindriwandestari1999@gmail.com

${ }^{2)}$ Alamat email enda.puspitasari@gmail.com

${ }^{3)}$ Alamat email yeni.solfiah@lecturer.unri.ac.id
} 


\section{PENDAHULUAN}

Negara maju adalah negara yang mempunyai sumber daya manusia yang berkualitas. Dengan adanya sumber daya manusia yang berkualitas bisa membawakan negara tersebut menjadi lebih maju karena banyaknya pengetahuan-pengetahuan dan ilmu-ilmu yang baru. Pendidikan memiliki peranan dan posisi penting dalam pembangunan. Pendidikan merupakan salah satu faktor yang paling utama dalam pembangunan sumber daya manusia yang berkualitas. Secara keseluruhan pembangunan mempersiapkan anak agar dapat berperan dimasa yang akan datang. Pendidikan merupakan proses komunikasi yang mengandung transformasi pengetahuan, nilai-nilai dan keterampilan-keterampilan di dalam dan di luar sekolah yang berlangsung sepanjang hayat dari generasi ke generasi (Dwi Swiswoyo, 2013).

Ilmu pendidikan juga mengalami perkembangan yang sangat pesat. Salah satunya adalah Pendidikan Anak Usia Dini. Pendidikan Anak Usia Dini (PAUD) pada hakikatnya ialah pendidikan yang diselenggarakan dengan tujuan untuk memfasilitasi pertumbuhan dan perkembangan anak secara menyeluruh atau menekankan pada pengembangan seluruh aspek kepribadian anak. Oleh karena itu, PAUD memberi kesempatan pada anak untuk mengembangkan kepribadian dan potensi secara maksimal. Konsekuensinya lembaga PAUD perlu menyediakan berbagai kegiatan yang dapat mengembangkan berbagai aspek perkembangan seperti: kognitif, bahasa, sosial, emosi, fisik, dan motorik.

Terdapat banyak hal yang anak pelajari di PAUD. Salah satu aspek yang harus dikembangkan adalah aspek kognitif. Menurut Santrock (dalam Luckrista, 2015) aspek dasar kognitif merupakan aspek pengembangan yang bertujuan mengembangkan kemampuan berpikir anak untuk mengembangkan kemampuan logis matematis dan pengetahuan akan ruang dan waktu, serta kemampuan untuk memilah-milah, mengelompokkan serta mempersiapkan kemampuan berpikir secara teliti. .

Anak usia dini dapat membangun pengetahuannya sendiri tentang matematika melalui bermain dan interaksi dengan lingkungannya. Seperti contoh ketika anak menyusun balok dan kemudian membandingkannya dengan susunan balok temannya. Secara langsung anak sudah mampu mengukur. Salah satu lingkup matematika untuk anak usia dini adalah mengukur. Dalam matematika pada anak usia dini umumnya dikenalkan bilangan, konservasi, serasi/pengurutan, klasifikasi, jarak, waktu dan kecepatan, pola, dan pengukuran.

Pengukuran adalah salah satu keterampilan paling berguna yang bisa dilakukan. Pengukuran melibatkan penetapan angka untuk hal-hal sehingga mereka dapat dibandingkan pada atribut yang sama. Angka dapat ditetapkan untuk atribut seperti volume, berat, panjang dan suhu (Charlesworth, 2012). Menurut Copley (2001) bahwa anak-anak memiliki konsep yang berkaitan dengan mengukur dan membandingkan hal-hal, maka sikap guru harus memberikan berbagai pengalaman dan komunikasi untuk membantu anak dalam mengeksplorasi dan membayangkan perbandingan dan pengukuran. Dalam memberikan berbagai pengalaman pada anak dibutuhkan beberapa media yang dapat menarik perhatian anak sehingga anak dapat melakukan pengukuran tanpa membebani otak anak.

Media adalah segala sesuatu yang dapat digunakan untuk menyampaikan pesan dari pengirim pesan kepada penerima pesan sehingga dapat merangsang pikiran, perasaan dan perhatian anak didik untuk tercapainya tujuan pembelajaran. Menurut Hairudin dalam (Guslinda dan Rita Kurnia, 2018) media adalah segala sesuatu yang dapat menyalurkan informasi dari sumber kepada penerima. Media dalam pembelajaran adalah segala bentuk alat komunikasi yang dapat digunakan untuk menyampaikan pesan atau informasi dari sumber pada anak didik yang bertujuan agar dapat merangsang pikiran, perasaan, minat dan perhatian anak didik untuk mengikuti kegiatan pembelajaran.

Media kolam ukur adalah media kolam kecil yang dirancang sedemikian rupa sehingga bisa jadi bahan ajar dan media untuk pembelajaran anak. Media kolam ukur ini dapat digunakan oleh anak untuk mengukur panjang, berat, volume/isi dan suhu. Media didesain semenarik mungkin agar dapat menarik minat anak serta sesuai dengan prinsip pembelajaran anak usia dini sehingga anak dapat tumbuh dan berkembang dengan optimal, serta tercapainya tujuan dari proses pembelajaran.

Pemberian rangsangan mengembangkan kemampuan pengukuran salah satunya dengan memanfaatkan media pembelajaran secara tepat dan sesuai dengan prinsip pembelajaran di 
Taman Kanak-kanak. Pembelajaran untuk konsep pengukuran hanya dikenalkan melalui kegiatan mengerjakan LKA, membandingkan besar kecilnya gambar, membandingkan tinggi rendahnya gambar lalu anak di suruh untuk mewarnai gambar tersebut tanpa ada objek yang nyata. Kurang kreatif dan variatifnya kegiatan dan media yang digunakan dalam mengenalkan konsep pengukuran pada anak, sehingga pemahaman anak tentang konsep pengukuran sedikit rendah. Padahal "pemahaman anak terhadap konsep hampir sepenuhnya tergantung pada pengalaman-pengalaman yang bersifat langsung (hand-on experiences) " (Sriningsih, 2008).

Berdasarkan pengamatan penulis pada anak usia 5-6 tahun di beberapa Taman Kanakkanak dan aspek yang ingin dicapai oleh anak usia dini adalah mengenal konsep pengukuran. Penulis melihat rata-rata kemampuan anak dalam mengenal konsep pengukuran masih rendah dan kemampuan anak dalam pengukuran belum sesuai dengan tahap-tahap perkembangan yang seharusnya, hal ini dapat dilihat seperti: 1) Sebagian anak belum mampu membandingkan benda menurut ukuran sedikit-banyak, besar-kecil, panjang-pendek, tinggi-rendah, berat-ringan. Contoh: pada saat anak mengerjakan lembar kerja kegiatan membandingkan dua buah benda yang memiliki panjang yang berbeda, sebagian besar anak masih ragu-ragu dan ada yang menjawab yang salah. 2) Sebagian besar anak belum mampu mengurutkan benda berdasarkan ukuran panjang ke pendek dan sebaliknya, berat ke ringan dan sebaliknya, banyak ke sedikit dan sebaliknya. Contoh: belum semua anak mampu menyebutkan ukuran yang benar pada dua buah cairan yang berbeda dan anak masih ragu untuk membandingkan banyak dan sedikitnya suatu objek seperti membandingkan jumlah gambar garpu yang ada pada lembar kerja anak. 3) Anak belum mampu menggunakan alat ukur (non standar) untuk mengukur panjang, berat, volume dan suhu. Contoh: guru menanyakan berapa panjang meja ini. Coba ukur menggunakan stik ini, disini anak belum mampu mengukur menggunakan alat ukur, anak kelihatan bingung saat mendengar perintah guru.

Berdasarkan pemaparan tersebut, penulis termotivasi untuk melakukan penelitian pengembangan media pembelajaran dengan tujuan memperbaiki kualitas pembelajaran dalam memahami konsep pengukuran dengan judul "Pengembangan Media Kolam Ukur untuk Meningkatkan Kemampuan Pengukuran pada Anak Usia 5-6 Tahun". Adapun tujuan penelitian ini adalah Untuk menghasilkan media kolam ukur yang layak untuk meningkatkan kemampuan pengukuran pada anak usia 5-6 tahun.

\section{METODE}

Jenis penelitian ini adalah penelitian dan pengembangan (Research \& Development) dengan mengacu pada model yang dikembangkan oleh Borg and Gall yang telah dimodifikasi oleh (Sugiyono 2013). Prosedur pengembangan dilakukan melalui beberapa tahap yaitu potensi dan masalah, mengumpulkan informasi, desain produk, validasi produk dan revisi produk.

Instrumen penelitian merupakan suatu alat yang digunakan dalam mengumpulkan data atau informasi sebagai suatu bagian penting dalam penelitian. Instrumen yang digunakan dalam penelitian ini berupa angket untuk ahli materi, angket untuk ahli media dan angket untuk praktisi. Pengujian instrumen dilakukan dengan menggunakan validasi, yakni dengan membandingkan isi instrumen dengan teori yang ada.

Dalam penelitian ini menggunakan teknik deskriptif untuk menganalisis data, sedangkan data kualitatif diubah menjadi data kuantitatif dengan cara mengelompokkan menjadi lima interval sebagai berikut:

Nilai 5 = Sangat Menarik

Nilai $4=$ Menarik

Nilai $3=$ Menarik dan Tidak (Netral)

Nilai 2 = Kurang Menarik

Nilai $1=$ Sangat Tidak Menarik

Sedangkan untuk menentukan hasil persentasi skor penilaiannya dengan menggunakan rumus perhitungan, yaitu sebagai berikut:

$$
P=\frac{F}{N} \times 100 \%
$$


Keterangan:

$\mathrm{P}=$ Angka persentase atau skor penilaian

$\mathrm{F}=$ Frekuensi yang sedang dicari persentasenya

$\mathrm{N}=$ Jumlah frekuensi/skor maksimal

Hasil dari skor penilaian menggunakan skala Likert tersebut kemudian dicari rata-ratanya dari sejumlah subjek sampel uji coba dikonservasikan pada pernyataan penilaian untuk menentukan kualitas dan tingkat kemanfaatan produk yang dihasilkan berdasarkan pendapat pengguna.

\begin{tabular}{cc}
\hline Skor & Kriteria \\
\hline $0 \% \leq \mathrm{x} \leq 20 \%$ & Tidak Layak \\
$21 \% \leq \mathrm{x} \leq 40 \%$ & Kurang Layak \\
$41 \% \leq \mathrm{x} \leq 60 \%$ & Cukup Layak \\
$61 \% \leq \mathrm{x} \leq 80 \%$ & Layak \\
$81 \% \leq \mathrm{x} \leq 100 \%$ & Sangat Layak \\
\hline
\end{tabular}

Sumber: Riduwan (2014)

\section{HASIL DAN PEMBAHASAN}

Media kolam ukur secara keseluruhan telah layak digunakan sebagai media pembelajaran untuk meningkatakan kemampuan pengukuran anak usia 5-6 tahun. Kelayakan tersebut didapat dari 5 langkah pengembangan menurut Borg \& Gall yang telah dimodifikasi oleh (Sugiyono 2013) dan disederhanakan oleh penulis. Tahapan ini meliputi: 1) Validasi ahli media, 2) Validasi ahli materi, 3) Validasi oleh 5 orang pendidik, 4) Revisi produk. Adapun hasil validasi oleh ahli sebagai berikut:

\begin{tabular}{clcc}
\hline No & \multicolumn{1}{c}{ Indikator } & Skor & Kriteria \\
\hline 1 & Jenis bahan yang digunakan & 4 & Menarik \\
2 & Keamanan bahan untuk digunakan anak & 4 & Menarik \\
& $\begin{array}{l}\text { dalam mengukur } \\
3\end{array}$ Ketahanan bahan media kolam ukur & 4 & Menarik \\
4 & Kesesuaian ukuran media kolam ukur & 5 & Sangat menarik \\
5 & Proporsi detail produk & 4 & Menarik \\
$6 \quad$ Komposisi pewarnaan & 4 & Menarik \\
$7 \quad$ Kesesuain produk dengan kemampuan & 3 & Netral \\
$\quad$ pengukuran anak & & Menarik \\
$8 \quad$ Kepraktisan produk & 4 & \\
Jumlah skor & 32 & \\
Skor maksimal & 40 & Layak \\
Rata-rata skor & 4 & \\
Rata rata persentase & $80 \%$ & \\
\hline
\end{tabular}

Hasil analisis validasi ahli media dilakukan dengan memperoleh skor 32 dengan rata-rata skor 4 dan rata-rata persentase sebesar $80 \%$ dengan kategori layak. Hal tersebut diperkuat dengan adanya penilaian dari ahli media bahwa produk media yang dikembangkan telah layak untuk diujicobakan dilapangan dengan perbaikan.

\begin{tabular}{clcc}
\hline No & \multicolumn{1}{c}{ Indikator } & Skor & Kriteria \\
\hline 1 & Kesesuaian KD dengan KI & 1 & Sangat Tidak Menarik \\
2 & Kesesuaian indikator dengan KD & 1 & Sangat Tidak Menarik \\
3 & $\begin{array}{l}\text { Kesesuaian materi dengan kegiatan } \\
\text { pembelajaran pengukuran }\end{array}$ & 4 & Menarik \\
4 & Kesesuaian materi dengan media kolam ukur & 4 & Menarik \\
5 & Ketepatan tata bahasa yang digunakan & 4 & Menarik \\
6 & Ketepatan dalam menggunakan tanda baca & 4 & Menarik
\end{tabular}


7 Kejelasan petunjuk penggunaan media kolam ukur

8 Melatih kemampuan fisik motorik anak usia dini

9 Melatih kemampuan kognitif anak usia dini

10 Melatih kemampuan sosial emosional anak usia dini

Jumlah skor

Skor maksimal

Rata-rata skor

Rata rata persentase
4

Menarik

5

5

5

37

50

3.7

$74 \%$
Sangat Menarik

Sangat Menarik

Sangat Menarik

Hasil analisis validasi ahli materi dilakukan dengan memperoleh skor 37 dengan rata-rata skor 3.7 dan rata-rata persentase sebesar $74 \%$ dengan kategori layak. Hal tersebut diperkuat dengan adanya penilaian dari ahli materi bahwa produk media yang dikembangkan telah layak untuk diujicobakan dilapangan dengan perbaikan.

\begin{tabular}{|c|c|c|c|c|}
\hline No & Indikator & $\begin{array}{l}\text { Jumlah } \\
\text { Skor }\end{array}$ & Persentase & Kriteria \\
\hline 1 & $\begin{array}{l}\text { Kemudahan media kolam ukur untuk } \\
\text { meningkatkan motivasi peserta didik } \\
\text { dalam mempelajari konsep } \\
\text { pengukuran }\end{array}$ & 22 & $88 \%$ & Sangat Layak \\
\hline 2 & $\begin{array}{l}\text { Kemampuan media kolam ukur } \\
\text { menambah pengetahuan peserta didik }\end{array}$ & 20 & $80 \%$ & Layak \\
\hline 3 & Informasi yang disampaikan jelas & 20 & $80 \%$ & Layak \\
\hline 4 & Kemanarikan media kolam ukur & 21 & $84 \%$ & Sangat Layak \\
\hline 5 & $\begin{array}{l}\text { Bahasa yang digunakan mudah } \\
\text { dipahami }\end{array}$ & 20 & $80 \%$ & Layak \\
\hline 6 & $\begin{array}{l}\text { Kemenarikan warna, desain dan } \\
\text { bentuk media kolam ukur }\end{array}$ & 21 & $84 \%$ & Sangat Layak \\
\hline 7 & $\begin{array}{l}\text { Kesesuaian produk dengan } \\
\text { kemampuan pengukuran anak }\end{array}$ & 19 & $76 \%$ & Layak \\
\hline \multicolumn{2}{|c|}{ Jumlah skor keseluruhan } & 143 & $572 \%$ & \\
\hline \multicolumn{2}{|c|}{ Skor maksimal } & 175 & $700 \%$ & \\
\hline \multicolumn{2}{|c|}{ Rata-rata skor } & 4 & $81.71 \%$ & Sangat Layak \\
\hline
\end{tabular}

Hasil analisis validasi ahli materi oleh pendidik dilakukan satu kali oleh 5 orang pendidik yang sudah sertifikasi dengan memperoleh skor 143 dengan rata-rata skor 4 dan rata-rata persentase sebesar $81.71 \%$ dengan kategori sangat layak. Hal tersebut diperkuat dengan adanya penilaian dari ahli materi bahwa produk media yang dikembangkan telah layak untuk diujicobakan dilapangan.

Media kolam ukur untuk meningkatkan kemampuan pengukuran anak usia 5-6 tahun telah selesai divalidasi dan dikembangkan oleh peneliti. Pembuatan media kolam ukur dimulai dengan pemilihan akrilik yang sesuai ketebalannya. Kemudian dilanjutkan dengan pemotongan akrilik sesuai dengan pola kolam ukur yang telah dirancangkan. Setelah pondasi awalnya siap, dilanjutkan dengan membuat dua buah timbangan yang mempunyai ketinggiaan yang berbeda, timbangan juga dibuat dari bahan dasar akrilik. Untuk membuat timbangan seimbang menggunakan baut yang dikunci tidak terlalu ketat sehingga timbangan bisa berada pada sebelah kiri dan kanan. Setelah itu dilanjutkan dengan membuat dan mempersiapkan perlengkapan lainnya seperti seluncuran, ember untuk timbangan dan sendok sensor panas. Setelah semua selesai dilanjutkan dengan menghias media kolam ukur agar anak lebih tertarik untuk menggunakannya. Penghiasan media kolam ukur hanya menggunakan gambar yang diprint sesuai dengan keinginan peneliti dan pewarnaan bisa disesuaikan dengan gambar. 
Peneliti menggunakan prosedur penelitian dan pengembangan dengan metode pengembangan Research and Development (R\&D). Pada pengembangan ini, untuk dapat menghasilkan produk media kolam ukur yang akan dikembangkan maka peneliti menggunakan prosedur penelitian dan pengembangan Borg and Gall yang telah dimodifikasi oleh (Sugiyono 2013) yaitu potensi dan masalah, mengumpulan informasi, desain produk, validasi produk dan revisi produk. Pada penelitian ini tidak ada uji coba, hanya sampai pada validasi kemudian di revisi. Hal ini dikarenakan adanya pandemi yaitu covid-19 sehingga peneliti tidak bisa terjun langsung ke lapangan.

Penelitian pengembangan yang dihasilkan adalah produk media kolam ukur yang layak untuk meningkatkan kemampuan pengukuran anak usia 5-6 tahun. Penelitian ini dilakukan untuk menyelesaikan masalah yang ada. Dimana permasalahan yang terdapat yaitu rendahnya kemampuan anak tentang konsep pengukuran dan kurangnya media yang menarik untuk merangsang pengetahuan anak tentang konsep pengukuran. Oleh karena itu, peneliti melakukan pengembangan media kolam ukur ini.

Berdasarkan beberapa masalah yang telah dijelaskan diatas, maka peneliti mencoba memberikan solusi untuk mengatasi masalah tersebut dengan melakukan penelitian pengembangan. Penelitian pengembangan dilakukan oleh peneliti dengan mengembangkan produk sebagai media bermain sambil belajar untuk anak usia 5-6 tahun. Produk yang telah dibuat dan dikembangkan kemudian divalidasi oleh ahli materi dan ahli media serta divalidasi oleh 5 orang pendidik yang sudah sertifikasi.

Pada saat melakukan perbaikan yang telah disarankan oleh ahli media, peneliti mengacu pada ciri-ciri media pembelajaran yang baik menurut (Andang Ismail 2009) yang berpendapat bahwa ciri-ciri media pembelajaran yang baik adalah permainan yang tidak membahayakan anak. Karena tingkat keamanan sebuah peralatan sangatlah membantu orang tua atau pendidik untuk mengawasi kegiatan anak. Maka dari itu, peneliti memperbaiki dengan cara menghaluskan sisi-sisi luar akrilik yang tajam sehingga tidak membahayakan anak sesuai dengan pendapat dari (Andang Ismail 2009).

Pada saat melakukan perbaikan yang telah disarankan oleh ahli materi maka peneliti mengacu pada pendapat (Mukmin 2004) yaitu materi pembelajaran merupakan salah satu komponen pembelajaran yang sangat penting dan sangat dibutuhkan dalam kegiatan belajar mengajar agar tujuan pembelajaran dapat tercapai. Maka dari itu, peneliti memperbaiki tujuan pembelajaran dengan materi sehingga adanya kesesuaian antara materi dengan tujuan pembelajaran.

Selanjutnya peneliti mengacu pada pendapat (Jacobs dan Crowley 2007) yang mengatakan bahwa pada akhir tahun prasekolah sebagian besar anak akan membandingkan ukuran benda (besar-kecil, panjang-pendek, tinggi rendah, berat-ringan, sedikit-banyak, dan panas-dingin). Dan peneliti juga mengacu pada pendapat (Roebyanto 2014) yang mengatakan bahwa pengukuran merupakan kegiatan membandingkan suatu besaran yang diukur dengan alat ukur yang digunakan sebagai satuan. Kemampuan pengukuran merupakan kapasitas seseorang dalam memahami kegiatan membandingkan suatu objek dengan objek lainnya baik mengukur tinggi rendah sebuah benda, berat dan lain-lain dengan menggunakan alat ukur yang sederhana. Maka dari itu peneliti memperbaiki media lebih mengenal pengukuran secara luas, tidak hanya mengenalkan panjang, berat, suhu dan volume saja tetapi juga mengenenalkan pengukuran tinggi-rendan dan besar-kecil.

Peneliti juga mengacu pada pendapat (Yofita 2013) yang mengatakan bahwa tahap perkembangan bahasa seorang anak dimulai dengan dapat mendengar dan membedakan bunyi suara, kata dan kalimat sederhana, dan mulai dapat berkomunikasi dengan bahasa suku kata, dua suku kata, menyusun kalimat sederhana dan seterusnya hingga melakukan komunikasi dengan bahasa yang lebih kompleks, dan selanjutnya anak juga mulai dapat memahami hubungan antara lisan dan tulisan dan hal tersebut berpengaruh pada kemampuan membaca dan menulis pada anak. Selain itu, rangsangan perlu dilakukan oleh orangtua ataupun guru untuk selalu mengajak anak berkomunikasi sehingga kemampuan bicara anak dapat berkembang. Maka dari itu, peneliti memperbaiki rpph pada pengembangan aspek bahasa lebih kompleks lagi sesuai dengan tahap perkembangan bahasa anak menurut (Yofita 2013). 
Berdasarkan nilai rata-rata hasil penilaian produk melalui validasi ahli media, ahli materi serta pendidik, hasil pengembangan dinyatakan "layak"digunakan untuk mengembangkan kemampuan pengukuran pada anak usia 5-6 tahun

\section{SIMPULAN}

Media kolam ukur berdasarkan penilaian ahli jika dirata-ratakan nilai secara keseluruhan dapat dikatogorikan dalam penilaian media kolam ukur layak untuk digunakan sebagai media untuk meningkatkan kemampuan pengukuran anak usia 5-6 tahun.

Sesuai dengan kesimpulan hasil penelitian, maka dapat dikemukakan beberapa rekomendasi, yaitu :

1. Rekomendasi untuk Pendidik

Media kolam ukur diharapkan dapat dipergunakan sebagai salah satu contoh dari variasi dalam pembelajaran dan dapat memotivasi anak dalam belajar dan sebagai guru hendaknya lebih kreatif dalam menentukan strategi pembelajaran, menciptakan suasana belajar yang menyenangkan.

2. Rekomendasi untuk Peneliti Selanjutnya

Hasil penelitian ini dapat dijadikan acuan dalam melakukan penelitian selanjutnya, agar peneliti lainnya dapat mencari alternatif dalam menghadapi permasalahan yang ada dengan pendekatan, metode, teknik, media atau strategi pembelajaran yang efektif. Karena semakin menarik suatu media pembelajaran kedepannya akan memberikan dampak positif bagi perkembangan anak dalam proses pembelajaran karena anak tidak merasa bosan dengan media pembelajaran yang monoton.

3. Rekomendasi untuk Pembaca

Pembaca dapat melakukan pengembangan lebih lanjut terhadap media pembelajaran terutama media kolam ukur agar dapat dihasilkan produk yang kreatif dan inovatif untuk digunakan dalam pembelajaran. Media kolam ukur ini dapat diuji cobakan pada kelompok yang lebih luas, bukan hanya sampai pada validasi saja tetapi diuji cobakan ke sekolah atau lembaga pendidikan lainnya untuk melihat seberapa besar pengaruh media kolam ukur dalam meningkatkan kemampuan pengukuran anak usia dini.

\section{DAFTAR PUSTAKA}

Andang Ismail. 2009. Education Game. Pro-U Media. Yogyakarta.

Charlesworth Rosalind. 2012. Experience in Math For Young Children. Wadsworth. Amerika.

Copley, V Juanita. 2001. The Young Child and Mathematics. National Association for the Education of Young Children. Washington DC.

Dwi Swiswoyo, dkk. 2013. Ilmu Pendidikan. UNY Press. Yogyakarta.

Goenawan Roebyanto. 2014. Geometri, Pengukuran dan Statistika. Gunung Samudera. Malang.

Guslinda dan Rita Kurnia. 2018. Media Pembelajaran Anak Usia Dini. Jakad Publishing. Surabaya.

Jacobs, Gera dan Kathy Crowley. 2007. Play, Projects, and Preschool Standards. Corwin Press. California.

Luckrista, E. J. A, dan Komala Sari. 2015. Pengaruh Permainan Kayu Malele Terhadap Kemampuan Mengenal Konsep Ukuran Anak. Skripsi, Fakultas Ilmu Pendidikan Universitas Negeri Surabaya.

Mukmin, N. 2004. Desain Pembelajaran. Program Pasca Sarjana UNY. Yogyakarta.

Rahayu Yofita Aprianti. 2013. Menumbuhkan Kepercayaan Diri Melalui Kegiatan Bercerita. Indeks. Jakarta.

Riduwan. 2014. Dasar-dasar Statistika.CV Alfabeta. Bandung.

Sriningsih, N. 2008. Pembelajaran Matematika Terpadu Untuk Anak Usia Dini. Pustaka Sebelas. Bandung.

Sugiyono. 2013. Metode Penelitian Pendidikan Kuantitatif dan Kualitatif dan R\&D. Alfatbeta. Bandung. 